\title{
Defective opsonisation and complement deficiency in serum from patients with fulminant hepatic failure
}

\author{
R J WYKE, I A RAJKOVIC, A L W F EDDLESTON, AND \\ ROGER WILLIAMS
}

From the Liver Unit, King's College Hospital and Medical School, London

SUMMARY Serum from 23 of 26 patients with fulminant hepatic failure and grade IV encephalopathy had defective opsonisation of $E$. coli and yeast ( $S$. cerevisiae). No toxic serum factors acting on the polymorphonuclear leucocytes or inactivators of the normal serum opsonisation factors were found. Complement deficiency was shown to be the most likely cause of the defect in opsonisation. The addition of a heat-labile fraction of normal serum at low concentration corrected the defect and factors of both the classical and the alternative pathways of complement were reduced to below $40 \%$ of the activity of the control serum. During the early stages of clinical recovery serum opsonisation and complement activity returned to normal with statistically significant correlations between tests of opsonisation and total haemolytic complement $\mathrm{CH}_{50}, \mathrm{C} 3$ and total alternative pathway activity. Defective serum opsonisation and complement deficiency represent major defects in the body's defences against infection.

Bacterial infection is a common complication of fulminant hepatic failure ${ }^{1}$ and has been implicated as the main cause of death in $11 \%$ of fatal cases. ${ }^{2}$ Normally the removal of bacteria from the blood requires serum factors, immunoglobulin, and complement, which coat (opsonise) the bacteria before they are ingested and killed by the polymorphonuclear leucocytes. Congenital deficiency of individual complement factors or immunoglobulin markedly increases susceptibility to infection. ${ }^{3-5}$ In this paper we describe investigations into opsonisation by serum from patients with fulminant hepatic failure. Two organisms, Escherichia coli and yeast (Saccharomyces cerevisiae), which have different opsonisation requirements were used. We also investigated the relationship between the opsonisation defect measured in vitro and the deficiency in complement factors in the same patients.

\section{Methods}

PATIENTS

Serum samples were obtained serially from 26 patients with fulminant hepatic failure after they had developed grade IV encephalopathy. The cause of their liver damage was paracetamol self-poisoning in 14, viral hepatitis in nine (two HBsAg-positive),

Received for publication 19 February 1980 and multiple exposure to halothane in three. Seven patients (two hepatitis, five paracetamol selfpoisoning) recovered completely. Full supportive therapy was given including intravenous dextrose, cimetidine, dexamethasone (for cerebral oedema), vitamin supplements, lactulose orally, and magnesium sulphate enemas. Liver support by means of daily periods of four to six hours' haemodialysis with a polyacrylonitrile membrane was needed in all patients, expecially in 11 who developed renal failure (creatinine $>200 \mu \mathrm{mol} / \mathrm{l}$ ). Three patients developed bacterial septicaemia after admission and a fourth had E. coli septicaemia on admission. Three of the four patients with infection survived and in the other the immediate cause of death was cerebral oedema rather than the infection. Antibiotics were given to three patients with proven infection and to nine with suspected bacterial infection.

Venous blood samples were taken daily before haemodialysis, from the time of the first signs of grade IV encephalopathy until death or recovery. Blood was allowed to clot for two hours at room temperature before separation of serum, which was either used immediately or stored in aliquots at $-196^{\circ} \mathrm{C}$ until the time of assay. Blood from 41 healthy medical and laboratory personnel aged between 18 and 40 years without evidence of liver disease or illness known to impair polymorphonuclear leucocyte function acted as controls. A 
control serum pool was derived from the sera of six controls, mixed in equal proportions, and stored in aliquots at $-196^{\circ} \mathrm{C}$.

PREPARATION OF POLYMORPHONUCLEAR LEUCOCYTES FOR $E$. col $i$ AND YEAST OPSONISATION ASSAYS

After sedimentation of erythrocytes with dextran (average molecular weight 26,400), the leucocyterich plasma fraction was layered onto a FicollTriosil gradients and centrifuged at $400-450 \mathrm{~g}$ for 20 minutes at $10-15^{\circ} \mathrm{C}$. The pellet containing polymorphonuclear leucocytes and erythrocytes was washed twice with a 1:2 mixture of ordinary and modified Hank's balanced salt solution, separated by centrifugation and the residual erythrocytes 'shocklysed' with distilled water for 10 seconds then made isotonic with equal volumes of $1.8 \%$ saline and ordinary Hank's balanced salt solution. The polymorphonuclear leucocytes were separated by centrifugation and resuspended in modified Hank's balanced salt solution. At least $90 \%$ of the cells isolated in this way were viable as judged by exclusion of trypan blue. The number of polymorphononuclear leucocytes was determined with a Neubauer chamber and a working suspension made with modified Hank's balanced salt solution.

\section{Escherichia coli OPSONISATION ASSAY}

Serum opsonisation of $E$. coli was measured by the method of Quie et al. ${ }^{6}$ E. coli 089 in the late logphase of growth, obtained by overnight culture at $30^{\circ} \mathrm{C}$ in trypticase soy broth, were washed twice with $0.9 \%$ saline at $4^{\circ} \mathrm{C}$ and the number of organisms estimated turbidometrically. The reaction mixture containing $2.5 \times 10^{6}$ polymorphonuclear leucocytes, $1 \times 10^{6} \mathrm{E}$. coli, and $40 \mu \mathrm{l}$ of test serum in a final volume of $1 \mathrm{ml}$ of Hank's balanced salt solution was incubated in air in polystyrene tubes on a Matburn rotary mixer for one hour at $37^{\circ} \mathrm{C}$. A $50 \mu$ l aliquot of reaction mixture was removed at zero and 60 minutes and the polymorphonuclear leucocytes lysed with $5 \mathrm{ml}$ of cold distilled water. The number of viable $E$. coli cells was determined by plating out in duplicate with the Miles-Misra technique onto MacConkey's agar and the number of colonyforming units (CFU) counted after overnight incubation at $37^{\circ} \mathrm{C}$.

Results were expressed as the opsonisation index: $\left[\begin{array}{c}\text { Mean number of CFU [in duplicates] } \\ \text { at } 60 \mathrm{~min}\end{array}\right] \times 100$ Control tubes included in each experiment contained: (a) E. coli+buffer; (b) E. coli+test serum; (c) $E$. coli + polymorphonuclear leucocytes + normal serum; (d) $E$. coli+polymorphonuclear leucocytes. The numbers of $E$. coli in control tubes (a), (b) and (d) never varied by more than $2 \%$ during the hour of incubation. Serum bactericidal and bacteriostatic activity was excluded by controls (b). Control (c) was used both as a standard and to establish the normal range. Serum from patients who received antibiotics was dialysed against Hank's balanced salt solution for 12 hours at $4^{\circ} \mathrm{C}$ and was shown to be without bactericidal or bacteriostatic effects by incubation with $E$. coli.

In the presence of polymorphonuclear leucocytes and serum from one control, opsonisation studied on four separate occasions gave a mean opsonisation index of $98 \cdot 72 \pm \mathrm{SD} 1 \cdot 19$. The variance for counting duplicate colony units was $3 \cdot 16 \%$.

\section{YEAST OPSONISATION ASSAY}

Yeast opsonisation was measured by the method of Levinsky et $a .^{7}{ }^{7}$ with a suspension of heat-inactivated bakers' yeast (Saccharomyces cerevisiae) in Hank's balanced salt solution mixed with normal polymorphonuclear leucocytes (in a ratio of yeast: polymorphonuclear leucocytes 10:1) and 5\% test serum in a final volume of $1 \mathrm{ml}$. After incubation at $37^{\circ} \mathrm{C}$ for 30 minutes in polystyrene tubes on a Matburn rotary mixer, the number of residual yeasts was counted with an electronic Coulter counter. Controls included in each experiment were (a) yeast + buffer; (b) yeast + polymorphonuclear leucocytes + buffer; (c) yeast + polymorphonuclear leucocytes + buffer + control serum pool. Control (a) provided a measure of the number of yeasts present in the reaction mixture after 30 minutes' incubation. Control (b) was used both to confirm the inability of polymorphonuclear leucocytes to ingest umoposonised yeasts and as a measure of the cellular content of the reaction mixture.

The opsonisation index $=$

$\left[\begin{array}{c}\text { Number of residual yeast cells after } \\ 30 \mathrm{~min}\end{array}\right] \times 100$

Results for test serum were expressed as a percentage of the activity of the control serum pool-control tube (c).

In the presence of polymorphonuclear leucocytes from one control, the control serum pool (studied on eight separate occasions) gave a mean opsonisation index of $77 \cdot 75 \pm$ SD $6 \cdot 25$ SEM 1.11. With polymorphonuclear leucocytes from 13 controls the control serum pool opsonised a mean of $78 \cdot 2 \pm S D$ 4.03 SEM $1 \cdot 11$ of the yeasts. 
SERUM COMPLEMENT AND

IMMUNOGLOBULIN ASSAYS

Functional activity of $\mathrm{C} 4, \mathrm{C} 5$, total haemolytic complement (CH50), total alternative pathway, and factors B and D were determined by haemolytic diffusion in agarose. ${ }^{8}{ }^{9}$ Immunoreactive $\mathrm{C} 3$ concentrations were determined by radial immunodiffusion against rabbit antiserum (kindly provided by Professor D K Peters). Results were expressed as the percentage activity of the control serum pool included as a standard in each plate. For some experiments, aliquots of serum pool were depleted of active C3 (R3), factor B (RB) and C4 (R4) by the method described by Lachman et al. ${ }^{8}$ Levels of serum immunoglobulin IgG, and IgM were measured in the serum of 19 of the patients with specific antisera (Behring Diagnostics, Hoechst UK Ltd, Hounslow, UK) and a laser nephelometer.

\section{Results}

Serum opsonisation indices for both $E$. coli and yeasts were reduced in all but three patients. $E$. coli opsonised by serum from 12 controls were almost all killed by normal polymorphonuclear leucocytes, mean opsonisation index being $98.5 \pm$ SD 1.2 . Opsonisation by serum from 22 patients was significantly reduced ( $P<0.01$, Wilcoxon's rank sum test), although the results were spread over a wide range, mean $40 \cdot 7 \pm 38 \cdot 7$. The mean yeast opsonisation index was also significantly reduced $(\mathbf{P}<\mathbf{0 . 0 1}$, Wilcoxon's rank sum test), although, in common with $E$. coli opsonisation, results for patients' serum were spread over a wide range, with a mean of $37 \pm 28.9$ compared with $98.7 \pm 7 \cdot 1$ for the control sera (Table 1). No correlation was found between this defect in serum opsonisation index for either

Table 1 Initial measurements of serum opsonisation (mean $\pm S D$ ) at time of grade IV encephalopathy

\begin{tabular}{|c|c|c|}
\hline & \multicolumn{2}{|l|}{ Opsonisation } \\
\hline & $\begin{array}{l}\text { Yeast } \\
\%\end{array}$ & $\begin{array}{l}\text { E. coli } \\
\%\end{array}$ \\
\hline Total series & $\begin{array}{l}37 \cdot 1 \pm 28.9 \\
(24)\end{array}$ & $\begin{array}{l}40 \cdot 7 \pm 38 \cdot 7 \\
(22)\end{array}$ \\
\hline Survivors & $\begin{array}{l}31 \cdot 8 \pm 27 \\
(7)\end{array}$ & $\begin{array}{l}23 \cdot 2 \pm 33 \cdot 6 \\
(6)\end{array}$ \\
\hline Fatalities & $\begin{array}{l}38 \cdot 8 \pm 30 \cdot 14 \\
(18)\end{array}$ & $\begin{array}{l}47 \cdot 3 \pm 39 \cdot 3 \\
(16)\end{array}$ \\
\hline $\begin{array}{l}\text { Paracetamol self- } \\
\text { poisoning }\end{array}$ & $\begin{array}{l}38 \cdot 6 \pm 26 \cdot 5 \\
(15)\end{array}$ & $\begin{array}{l}31 \pm 30 \cdot 3 \\
(10)\end{array}$ \\
\hline Viral hepatitis & $\begin{array}{l}29 \cdot 4 \pm 25 \cdot 7 \\
(8)\end{array}$ & $\begin{array}{l}55 \pm 42 \cdot 6 \\
(9)\end{array}$ \\
\hline Controls & $\begin{array}{l}98 \cdot 7 \pm 7 \cdot 1 \\
(38)\end{array}$ & $\begin{array}{l}98 \cdot 5 \pm 1 \cdot 2 \\
(12)\end{array}$ \\
\hline
\end{tabular}

Figures in parentheses show number of patients studied. organism and the aetiology or clinical outcome of the hepatic necrosis.

The results of the serial measurements in 10 of the fatal cases showed a progressive reduction in opsonisation indices in eight while, in seven of the patients who recovered, serial studies were available during the period of improvement in five. In all cases serum opsonisation indices for both $E$. coli and yeasts returned to normal, in three patients between one and nine days after all signs of encephalopathy had disappeared (between two and 10 days after admission). There was, however, no correlation with the level of consciousness, some minor signs of encephalopathy still being present in two other patients when opsonisation indices had returned to normal.

Experiments with polymorphonuclear leucocytes from four patients, in the presence of autologous serum, showed the $E$. coli opsonisation index to be reduced, with a mean value of 31.5 . In the presence of control serum pool the cells functioned normally, with a mean opsonisation index of $98 \cdot 75$.

CHARACTERISATION OF SERUM ABNORMALITY Dialysis in vitro against Hank's balanced salt solution for 12 hours at $4^{\circ} \mathrm{C}$ had no effect; mean yeast opsonisation index in the five patients studied was 60.5 before and 53 after dialysis $(P>0.5$, paired $t$-test). Similarly, serum obtained immediately before and after treatment by polyacrylonitrile membrane dialysis in five patients gave mean opsonisation values for yeast of 56.3 and 39 respectively and for $E$. coli 88.3 and 76.3 respectively (Table 2 ). These findings indicate that the serum defect was not caused by a toxic substance of low molecular weight.

To examine for the action of a non-dialysable toxic serum factor, normal polymorphonuclear leucocytes were incubated for one hour at $37^{\circ} \mathrm{C}$ in a $10 \%$ dilution of serum from nine patients known to have defective opsonisation. When normal polymorphonuclear leucocytes treated in this way were incubated with $E$. coli or yeast cells already opsonised

Table 2 Measurements of serum opsonisation before and after four hours of polyacrylonitrile haemodialysis in five patients

\begin{tabular}{lllllll}
\hline Patient & Aetiology & \multicolumn{2}{l}{ Opsonisation index } \\
\cline { 3 - 4 } & & \multicolumn{2}{l}{ Yeast } & & \multicolumn{2}{l}{ E. coli } \\
\cline { 3 - 4 } \cline { 5 - 6 } & & Before & After & & Before & After \\
\hline 1 & Hepatitis & 105 & 54 & 92 & 71 \\
2 & Halothane & -72 & -70 & & 91 & 67 \\
3 & Hepatitis & 72 & 70 & & 91 \\
4 & Hepatitis & 0 & 0 & & - & - \\
5 & Paracetamol & 48 & 32 & & - & $\overline{76.3}$ \\
Mean & & 56.3 & 39 & & & \\
\hline
\end{tabular}


Table 3 Effects of dilutions of control serum on yeast opsonisation by serum from three patients

\begin{tabular}{|c|c|c|c|c|}
\hline \multicolumn{5}{|c|}{ Final concentration $(\%)$ serum in reaction mixture } \\
\hline Control serum & $\mathbf{0}$ & 0.5 & 1 & 2 \\
\hline $\begin{array}{l}\text { Patients' serum } \\
\text { Serum of patient } 1 \\
\text { Serum of patient } 2 \\
\text { Serum of patient } 3\end{array}$ & $\begin{array}{r}5 \\
56 \\
75 \\
75\end{array}$ & $\begin{array}{l}4 \cdot 5 \\
99\end{array}$ & $\begin{array}{r}4 \\
100 \\
98 \\
104\end{array}$ & $\begin{array}{r}3 \\
99 \\
101 \\
105\end{array}$ \\
\hline $\begin{array}{l}\text { Control serum } \\
\text { diluted with buffer }\end{array}$ & $\mathbf{0}$ & $14 \cdot 3$ & 53 & 100 \\
\hline
\end{tabular}

Numbers do not denote the same patients as in Table 2

by preincubation in control serum pool, a mean of $99.3 \%$ E. coli and $100 \%$ yeast cells were phagocytosed, indicating no impairment of leucocyte function.

To determine whether the defect was due to a deficiency of normal opsonisation factors, serum from patients and from control serum pool were mixed together in different porportions. Severe defects of $E$. coli opsonisation by serum from three cases were totally corrected by the addition of control serum pool at concentrations of $0 \cdot 25,0.33$, and $2 \%$. As control serum pool in a concentration of $1 \%$ in the absence of patients' serum was only able to opsonise $35 \%$ of $E$. coli, the contribution by patients' serum in these experiments is greater than immediately apparent. Similar studies of yeast opsonisation by serum from three other patients showed that the defect could be totally corrected by addition of 0.5 and $1 \%$ control serum pool (Table 3 ), while control serum pool at a concentration of 0.5 and $1 \%$ in the absence of patients' serum opsonised only 14 and $53 \%$ of yeasts respectively (Table 4 ). Heating of control serum to $56^{\circ} \mathrm{C}$ for 30 minutes abolished the beneficial effect even at a concentration as high as $5 \%$.
RELATIONSHIP BETWEEN SERUM COMPLEMENT AND DEFECTS OF OPSONISATION

When factors of the classical and alternative pathways of complement were measured at the same time as opsonisation indices, reduction in concentration were found in 24 of 25 cases with mean values of less than $40 \%$ of the activity of the control serum pool (Table 4). Levels of $\mathrm{CH} 50, \mathrm{C} 3, \mathrm{C} 4$, and $\mathrm{C} 5$ were higher in cases of viral hepatitis than in those with paracetamol self-poisoning, although only C4 reached statistical significance. The only serum with normal complement activity had normal opsonisation of $E$. coli, but impaired yeast opsonisation. Defective opsonisation was found in 22 of the 24 cases with complement deficiency. Serial studies in 11 of the fatal cases showed a further reduction in complement levels and opsonisation indices in 10. In the remaining case there was a $26 \%$ mean increase in factor $\mathrm{B}, \mathrm{CH} 50, \mathrm{C} 3, \mathrm{C} 4$, and $\mathrm{C5}$ after transfusion of 11 units of blood and 2 units of fresh frozen plasma over four days and in this case $E$. coli opsonisation also increased (from 0 to 99). However, five of the cases with progressive defects had also received transfusions but of smaller amounts ( 2 units of fresh frozen plasma or blood). The relationship between the changes in complement factors and opsonisation defect was examined by the ability of normal serum depleted of C3 (R3) or factor B (RB) or C4 (R4) to correct opsonisation in vitro. In three cases $E$. coli opsonisation was still defective after the addition of R3 or R4 but was fully corrected by the addition of $\mathrm{RB}$.

In six of the seven patients (two hepatitis, five paracetamol self-poisoning) who regained consciousness, complement factor activity returned to normal in four cases between three and nine days and in two cases between time of discharge (two and nine days respectively after all signs of encephalopathy had disappeared) and follow-up at one and

Table 4 Initial measurements of serum complement expressed as percentage activity of serum pool (mean $\pm S D)$

\begin{tabular}{|c|c|c|c|c|c|c|c|}
\hline Clinical groups & Factor $B$ & Factor D & $\begin{array}{l}\text { Alternative } \\
\text { pathway }\end{array}$ & $\begin{array}{l}\text { Total } \\
\text { haemolytic } \\
\text { complement } \\
(\text { CH50) }\end{array}$ & C3 & $C 4$ & C5 \\
\hline Total series & $\begin{array}{l}26 \cdot 4 \pm 25.9 \\
(25)\end{array}$ & $\begin{array}{l}29 \cdot 1 \pm 28 \cdot 8 \\
(16)\end{array}$ & $\begin{array}{l}22 \cdot 6 \pm 17 \cdot 2 \\
(25)\end{array}$ & $\begin{array}{l}12 \cdot 3 \pm 15 \cdot 1 \\
(23)\end{array}$ & $\begin{array}{l}23 \cdot 8 \pm 11 \cdot 6 \\
(25)\end{array}$ & $\begin{array}{l}15 \cdot 9 \pm 13 \cdot 1 \\
(24)\end{array}$ & $\begin{array}{l}15 \cdot 4 \pm 17 \cdot 1 \\
(15)\end{array}$ \\
\hline Fatalies & $\begin{array}{l}25 \cdot 2 \pm 28 \cdot 8 \\
(18)\end{array}$ & $\begin{array}{l}23 \pm 30 \cdot 9 \\
(10)\end{array}$ & $\begin{array}{l}21 \cdot 6 \pm 17 \cdot 5 \\
(18)\end{array}$ & $\begin{array}{l}13.5 \pm 15.9 \\
\text { (17) }\end{array}$ & $\begin{array}{l}24 \cdot 1 \pm 13 \cdot 1 \\
(18)\end{array}$ & $\begin{array}{l}15.9 \pm 12.9 \\
(18)\end{array}$ & $\begin{array}{l}18.3 \pm 19.5 \\
(10)\end{array}$ \\
\hline Survivors & $\begin{array}{l}29 \cdot 7 \pm 17 \cdot 6 \\
\text { (7) }\end{array}$ & $\begin{array}{l}39 \cdot 2 \pm 23 \cdot 8 \\
\text { (6) }\end{array}$ & $\begin{array}{l}25 \cdot 6 \pm 17 \cdot 5 \\
\text { (7) }\end{array}$ & $\begin{array}{l}9 \cdot 3 \pm 13 \cdot 7 \\
\text { (7) }\end{array}$ & $\begin{array}{l}23 \pm 7 \cdot 4 \\
(7)\end{array}$ & $\begin{array}{l}16 \cdot 2 \pm 14 \cdot 8 \\
(6)\end{array}$ & $\begin{array}{l}9 \cdot 6 \pm 10 \\
(5)\end{array}$ \\
\hline Paracetamol self-poisoning & $\begin{array}{l}26 \cdot 7 \pm 24 \cdot 5 \\
(14)\end{array}$ & $\begin{array}{l}31 \cdot 1 \pm 24 \cdot 2 \\
\text { (9) }\end{array}$ & $\begin{array}{l}18 \cdot 5 \pm 17 \cdot 1 \\
(15)\end{array}$ & $\begin{array}{l}6 \cdot 4 \pm 8 \cdot 4 \\
(14)\end{array}$ & $\begin{array}{l}20.4 \pm 8.6 \\
(14)\end{array}$ & $\begin{array}{l}11.4 \pm 11.8^{*} \\
(14)\end{array}$ & $\begin{array}{l}8 \cdot 8 \pm 12 \cdot 1 \\
\text { (9) }\end{array}$ \\
\hline Viral hepatitis & $\begin{array}{l}32 \cdot 1 \pm 31 \cdot 7 \\
\text { (8) }\end{array}$ & $\begin{array}{l}37 \pm 37 \cdot 7 \\
\text { (4) }\end{array}$ & $\begin{array}{l}26 \cdot 8 \pm 20 \cdot 1 \\
(8)\end{array}$ & $\begin{array}{l}26 \cdot 4 \pm 18 \cdot 6 \\
\text { (7) }\end{array}$ & $\begin{array}{l}32 \cdot 3 \pm 14 \\
(8)\end{array}$ & $\begin{array}{l}23 \cdot 9 \pm 12 \cdot 1^{*} \\
\text { (7) }\end{array}$ & $\begin{array}{l}33 \cdot 8 \pm 18 \cdot 9 \\
\text { (4) }\end{array}$ \\
\hline
\end{tabular}

Figures in parentheses represent number of patients studied.

$* 0.05>P>0.02$ (Wilcoxon's rank sum test). 


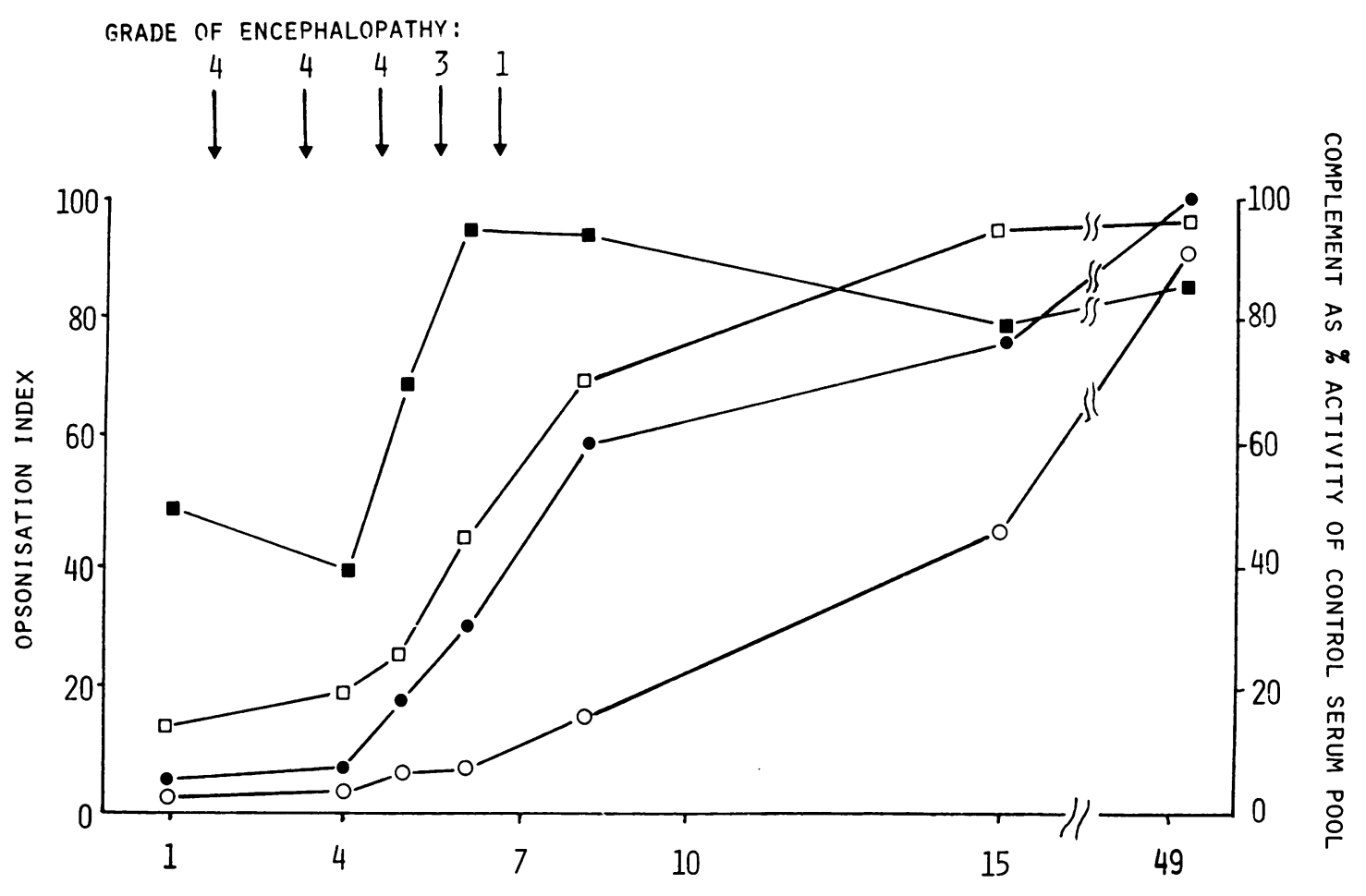

DAYS AFTER ADMISSION

Figure Serial values of serum opsonisation and complement levels in a case of paracetamol self-poisoning while in grade IV encephalopathy and during the acute stages of recovery. $\square-\square \mathrm{E}$. coli opsonisation. $\square$ Yeast opsonisation. - Alternative pathway activity. $\bigcirc-\bigcirc$ Total haemolytic complement (CH5O).

six months respectively. The activity of the alternative pathway tended to recover earlier and more rapidly than that of the classical pathway and was paralleled by a return to normal of opsonisation (Figure). The increase in $E$. coli opsonisation during recovery correlated with the activity of the total alternative pathway $(r=0.81, P<0.001)$ and $\mathrm{C} 3$ $(r=0.65, \mathrm{P}<0.001)$, while recovery of yeast opsonisation correlated only with levels of the total haemolytic complement $\mathrm{CH} 50(r=0.63, \mathrm{P}<0.01)$.

\section{Discussion}

In considering the possible causes for the defective in-vitro tests of opsonisation found in the present patients, a primary defect in the polymorphonuclear leucocytes can be excluded as the cells functioned normally when control serum was used in the assay. This contrasts with reported findings in other studies of leucocyte function in patients with fulminant hepatic failure ${ }^{1011}$ and in children who are carriers of hepatitis B surface antigen. ${ }^{12}$ Saunders et al. ${ }^{13}$ attributed impaired killing of $E$. coli by normal polymorphonuclear leucocytes in serum from patients with acute viral hepatitis to the action of a virus-related serum antagonist on the leucocyte. In our patients, however, normal polymorphonuclear leucocytes functioned normally after preincubation in patients' serum and the failure of both haemodialysis and in-vitro dialysis to improve opsonisation excludes the action of a toxic serum factor of low molecular weight. Furthermore, similar defects of opsonisation were found in sera from patients with fulminant hepatic failure caused by paracetamol self-poisoning and halothaneassociated necrosis as in fulminant viral hepatitis. The low concentration of normal serum needed to correct the opsonisation defect indicates a deficiency in opsonisation factors rather than the action of an inhibitor or inactivator.

$E$. coli opsonisation requires the action of serum immunoglobulins IgM and IgG and complement C3, produced mainly by activation of the classical pathway, ${ }^{14}$ whereas yeast opsonisation is dependent solely on complement, activated via the alternative pathway. ${ }^{15}$ The heat lability and low concentration 
of normal serum needed to correct the opsonisation defect is consistent with complement deficiency rather than immunoglobulin as the cause of the defective opsonisation. Additional evidence is the reduction of complement factors in the sera of patients at a time when opsonisation defects were most markedly affected and the good correlations between improvement in serum opsonisation and complement activity during the acute stages of recovery. The correlation between the recovery of the alternative pathway activity and $E$. coli opsonisation should be interpreted with caution, in view of the correction achieved by the addition of normal serum depleted of factor $B(R B)$, which suggests a defect in the classical pathway.

The liver is the major site of synthesis of complement factors and the fact that serum complement and opsonisation returned to normal during recovery is evidence that these defects are not congenital but secondary to the hepatic necrosis. Markedly lowered complement levels have been reported in patients with acute hepatic necrosis ${ }^{16}$ and less severe defects in viral hepatitis due either to reduced synthesis or increased catabolism. ${ }^{17-19}$ In our patients consumption of complement may have been increased especially in cases with acute viral hepatitis in whom circulating immune complexes are raised. Similar defects in complement and opsonisation, however, were present in hepatic necrosis caused by paracetamol self-poisoning (D Vergani, personal communication) in which immune complexes are almost always absent. The complement deficiences in our patients are severe and affect several factors to a degree associated with impaired host defence against infection in other congenital and acquired complement deficiency states. ${ }^{3-5} 20$

The importance of these findings is shown by the occurrence of bacterial infection in four $(15 \%)$ of the cases at a time when serum opsonisation and complement factors were severely reduced. Reports of congenital deficiency of serum opsonisation ${ }^{21}$ suggest that transfusions of fresh blood or freshly prepared plasma provide the most effective replacement therapy. While opsonisation returned to normal in one patient, the failure of small transfusions of fresh frozen plasma in other cases may have been due to the insufficient volume of the transfusion or to the fact that the plasma had been stored and was not freshly separated. As in other diseases, infection can be overwhelming in the presence of such defects of host defence and attempts to correct these in fulminant hepatic failure should prove worthwhile.

We are grateful to Dr $\mathbf{M}$ Eibl for provision of $E$. coli strain 089 and to Immuno Ltd for the generous financial support of RJW and IR. Professor J R Soothill and Professor D K Peters gave valuable technical advice.

\section{References}

${ }^{1}$ Mummery RV, Bradley JM, Jeffries DJ. Microbiological monitoring of patients in hepatic failure with particular reference to extracorporeal porcine liver perfusion. Lancet 1971; 2: 60-4.

${ }^{2}$ Gazzard BG, Portmann B, Murray-Lyon IM, Williams $R$. Causes of death in fulminant hepatic failure and relationship to qualitative histological assessment of parenchymal damage. $Q J$ Med 1975 ; 44: 615-26.

${ }^{3}$ Abramson N, Alper CA, Lachmann PJ, Rosen FS, Jandl JH. Deficiency of C3 in activator in man. $J$ Immunol 1971; 107: 19-27.

${ }^{4}$ Alper CA, Colten HR, Rosen FS, Rabson AR, MacNab GM, Gear JSS. Homozygous deficiency of C3 in a patient with repeated infections. Lancet 1972: 2: 1179-1181.

${ }^{5}$ Clark RA, Klebanoff SJ. Role of the classical and alternative complement pathways in chemotaxis and opsonization: studies of human serum deficient in C4. J Immunol 1978; 120: 1102-8.

${ }^{6}$ Quie P, White JG, Holmes B, Good R. In-vitro bactericidal capacity of human polymorphonuclear leukocytes: diminished activity in chronic granulomatous disease of childhood. J Clin Invest 1967; 46: 668-679.

${ }^{7}$ Levinsky RJ, Harvey BAM, Paleja S. A rapid objective method for measuring the yeast opsonisation activity of serum. J Immunol Methods 1978; 24: 251-256.

${ }^{8}$ Lachmann PJ, Hobart MJ, Aston WP. Complement technology. In: Weir DM, ed. Handbook of experimental immunology. Oxford: Blackwell Scientific Publications, 2nd edn, chap. 5, 1973: 7-12.

${ }^{9}$ Martin A, Lachmann PJ, Halbwachs L, Hobart MJ. Haemolytic diffusion plate assays for Factors B andD of the alternative pathway of complement activation. Immunochemistry 1976; 13: 317-24.

${ }^{10}$ Bailey RJ, Woolf IL, Cullens H, Williams R. Metabolic inhibition of polymorphonuclear leucocytes in fulminant hepatic failure. Lancet 1976: 1: 1162-3.

${ }^{11}$ Alam AN, Poston LP, Wilkinson SP, Golindano CG, Williams $R$. A study in vitro of the sodium pump in fulminant hepatic failure. Clin Sci Mol Med 1978; 55: $355-63$.

${ }^{12}$ Vierucci A, De Martino M, London WT, Blumberg BS. Neutrophil function in children who are carriers of hepatitis-B surface antigen. Lancet 1977; 1: 157-161.

${ }^{13}$ Saunders SJ, Dowdle EB, Fiskerstrand C, Bassedine M, Walls R. Serum factor affecting neutrophil function during acute viral hepatitis. Gut 1978; 19: 930-4.

${ }^{14}$ Van Oss CJ, Gillman CF. Phagocytosis as a surface phenomenon. II. Contact angles and phagocytosis of encapsulated bacteria before and after opsonisation by specific antiserum and complement. $J$ Reticuloendothel Soc 1972; 12: 497-502.

${ }^{15}$ Soothill JF, Harvey BAM. A defect of the alternative pathway of complement. Clin Exp Immunol 1977; 27: 30-3. 
${ }^{16}$ Pagaltsos AP, Smith MGM, Eddleston ALWF, Williams R. Total haemolytic complement after liver transplantation and in liver disease. Transplantation 1972; 14: 41-6.

${ }^{17}$ Kosmidis JC, Leader-Williams LK. Complement levels in acute infectious hepatitis and serum hepatitis. Clin Exp Immunol 1972; 11: 31-5.

${ }^{18}$ Kourilsky O, Leroy C, Peltier AP. Complement and liver cell function in 53 patients with liver disease. Am J Med 1973; 55: 783-90.
${ }^{19}$ Charlesworth JA, Lawrence S, Worsdall PA, Roy LP, Boughton CR. Acute hepatitis: significances of changes in complement components. Clin Exp Immunol 1977; 28: 496-501.

${ }^{20}$ Jasin HE, Orozco JH, Ziff M. Serum heat-labile opsonins in systemic lupus erythematosus. J Clin Invest 1974; 53: 343-53.

${ }^{21}$ Miller ME, Seals J, Kaye R, Levitsky LC. A familial, plasma-associated defect of phagocytosis. Lancet 1968; 2: 60-63. 